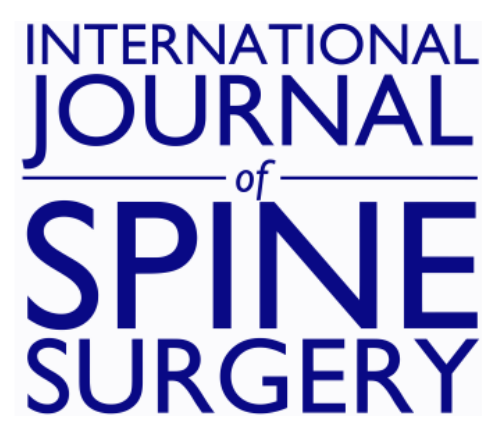

\title{
Pathomechanism and Biomechanics of Degenerative Disc Disease: Features of Healthy and Degenerated Discs
}

Sertac Kirnaz, Charisse Capadona, Marianne Lintz, Byumsu Kim, Rachel Yerden, Jacob L. Goldberg, Branden Medary, Fabian Sommer, Lynn B. McGrath, JR, Lawrence J. Bonassar and Roger Härtl

Int J Spine Surg 2021, 15 (s1) 10-25

doi: https://doi.org/10.14444/8052

http://ijssurgery.com/content/15/s1/10

This information is current as of April 26, 2023.

Email Alerts Receive free email-alerts when new articles cite this article. Sign up at: http://ijssurgery.com/alerts 


\title{
Pathomechanism and Biomechanics of Degenerative Disc Disease: Features of Healthy and Degenerated Discs
}

\author{
SERTAC KIRNAZ, MD ${ }^{1}$ CHARISSE CAPADONA, BS, ${ }^{1}$ MARIANNE LINTZ, MS, ${ }^{2}$ BYUMSU KIM, BS, ${ }^{3}$ \\ RACHEL YERDEN, BS, ${ }^{2}$ JACOB L. GOLDBERG, MD, ${ }^{1}$ BRANDEN MEDARY, BA, ${ }^{1}$ FABIAN SOMMER, \\ MD ${ }_{1}^{1}$ LYNN B. MCGRATH JR, MD ${ }^{1}$ LAWRENCE J. BONASSAR, PHD,${ }^{2,3}$ ROGER HÄRTL, MD ${ }^{1}$ \\ ${ }^{I}$ Department of Neurological Surgery, Weill Cornell Brain and Spine Center, Weill Cornell Medicine, New York Presbyterian Hospital, New York, New York, \\ ${ }^{2}$ Meinig School of Biomedical Engineering, Cornell University, Ithaca, New York, ${ }^{3}$ Sibley School of Mechanical and Aerospace Engineering, Cornell University, \\ Ithaca, New York
}

\begin{abstract}
The human intervertebral disc (IVD) is a complex organ composed of fibrous and cartilaginous connective tissues, and it serves as a boundary between 2 adjacent vertebrae. It provides a limited range of motion in the torso as well as stability during axial compression, rotation, and bending. Adult IVDs have poor innate healing potential due to low vascularity and cellularity. Degenerative disc disease (DDD) generally arises from the disruption of the homeostasis maintained by the structures of the IVD, and genetic and environmental factors can accelerate the progression of the disease. Impaired cell metabolism due to $\mathrm{pH}$ alteration and poor nutrition may lead to autophagy and disruption of the homeostasis within the IVD and thus plays a key role in DDD etiology. To develop regenerative therapies for degenerated discs, future studies must aim to restore both anatomical and biomechanical properties of the IVDs. The objective of this review is to give a detailed overview about anatomical, radiological, and biomechanical features of the IVDs as well as discuss the structural and functional changes that occur during the degeneration process.
\end{abstract}

Special Issue

Keywords: degenerative disc disease, pathophysiology, biomechanics, intervertebral disc, back pain, low back pain, lumbar disc herniation

\section{INTRODUCTION}

Chronic lower back pain (LBP) is one of the leading causes of disability and imposes a significant medical, economic, and social burden worldwide. ${ }^{1}$ Moreover, its prevalence is continuously increasing, especially in high-income countries. ${ }^{2}$ Although the etiology is not always clear, LBP often originates from the intervertebral disc (IVD), sacroiliac joint, facet joint, and soft tissues. ${ }^{3}$ Among other pathologies, up to $40 \%$ of LBP cases are associated with degenerative disc disease (DDD), which is due to neoinnervation and inflammation within the degenerated discs ${ }^{4}$ (Figure 1). Treatment methods such as physical therapy, non-steroidal anti-inflammatory drugs (NSAIDs), and steroid injections are commonly used for alleviating discogenic pain. 5,6 However, neither operative nor nonoperative treatment methods actually address the underlying disease.

In recent years, biological treatment methods including gene therapy, growth factor and cell-based injections, as well as tissue-engineered approaches including nucleus pulposus (NP) augmentation, annulus fibrosus (AF) repair, and total disc replacement have been extensively investigated to prevent further degeneration and promote IVD regeneration. $^{7-13}$ Although most of these novel therapies are still limited to in vitro and in vivo animal models, an increasing number of clinical trials have been conducted within the last decade. $^{11,14}$ To develop newer, safer, and more effective therapeutic approaches, it is crucial to understand the underlying pathomechanism of DDD.

Our group previously published a comprehensive textbook which gives a detailed overview of biological treatment approaches for IVD regeneration. ${ }^{15}$ In this review, we aim to share the comprehensive data on the prevalence of LBP and lumbar disc herniation $(\mathrm{LDH})$ to emphasize the importance of innovative biological treatment methods. We also cover relevant embryology, anatomy, and physiology of the IVDs. In addition, we discuss the structural and functional changes as 


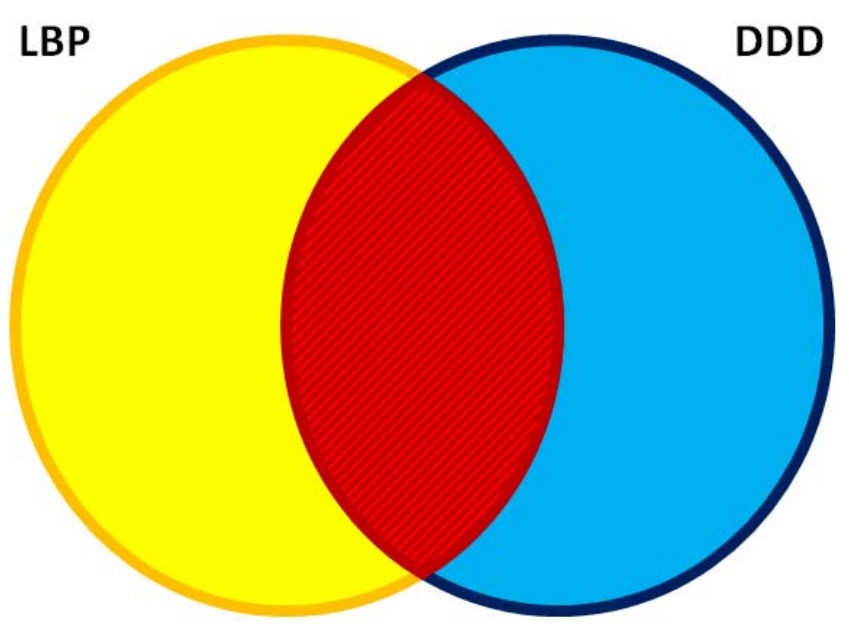

Figure 1. Low back pain (LBP) is a clinical entity, and degenerative disc disease (DDD) is a radiographic-anatomical finding. There are many reasons why patients can present with LBP. Conversely, DDD is frequently found in imaging studies of asymptomatic patients. However, there is an overlap, and patients with LBP can present with imaging findings consistent with DDD. The challenge for the clinician then is to establish whether there is a causative relationship.

well as the inflammatory responses that occur during IVD degeneration. Finally, we compare radiological and biomechanical features between healthy and diseased discs to highlight the effects of DDD.

\section{Prevalence of LBP and LDH}

In a systematic review on the global prevalence of LBP, Hoy et $\mathrm{al}^{16}$ in 2008 reported a point prevalence of $11.9 \pm 2.0 \%$, a 1 -year prevalence of $38.0 \pm 19.4 \%$, and a lifetime prevalence of $39.9 \pm$ $24.3 \%$. The authors also demonstrated a strong positive correlation between the mean prevalence of LBP and a nation's human development index, although a significant difference for prevalence between rural and urban areas was not found. In a meta-analysis by Ravindra et $\mathrm{al}^{17}$ in 2018 , the global incidence of patients with degenerative lumbar disorder and LBP was found to occur 3 times more frequently in low- and middle-income countries than in high-income countries. A significant increase in the prevalence of chronic LBP over a 14-year interval has been reported by Freburger et $\mathrm{al}^{18}$ while severity of symptoms and general health conditions were unchanged during this period. The rise in prevalence of LBP is possibly accounted for by the recent increased propensity to crucial risk factors such as obesity, sleep deprivation, and chronic stress. ${ }^{19}$ Other significant risk factors associated with LBP include smoking and occupational hazards such as heavy lifting and poor posture. $^{20,21}$ However, prevalence estimates of LBP in older adults vastly differ due to the lack of a standard definition of LBP and variations in sampling and experimental methods as reported by clinical and administrative studies. ${ }^{22}$ Authors of these studies also provide limited information regarding location and severity of pain, as well as LBP-induced limitations on normal functioning. Nevertheless, LBP persists as a worldwide problem according to the 2010 Global Burden of Disease Study $^{1}$ : LBP is deemed as the leading cause of years lived with disability and sixth highest burden in terms of disability-adjusted life years. The economic impact of degenerative spinal disorders in the United States alone is estimated between \$20 billion to $\$ 50$ billion per year. ${ }^{23}$ According to the Healthcare Cost and Utilization Project, at least 900,000 spinal surgeries are performed annually in the US including 413,000 spinal fusions, 370,000 discectomies, and 103,000 laminectomies. ${ }^{24-26}$

Several studies have suggested that at least $40 \%$ of LBP is associated with DDD, and patients showing increased modic changes in magnetic resonance imaging (MRI) scans are more likely to have LBP. ${ }^{4,5,27}$ However, the relationship between DDD and LBP remains controversial in the literature since MRI findings do not necessarily correspond to clinical outcomes, and the etiology of pain is often unclear. ${ }^{28}$ Pain can arise from degenerated discs via 2 different yet usually cooccurring mechanisms: (1) radicular pain due to disc bulging and subsequent compression of nerve roots and (2) discogenic pain without disc herniation. ${ }^{29}$

LDH is often caused by a tear in the AF due to preexisting degenerative changes in the IVD. However, LDH can also be observed in early stages of DDD and can exacerbate the degenerative process. ${ }^{30}$ The treatment method chosen is crucial since more invasive procedures may accelerate disc degeneration, whereas regenerative therapies can prevent long-term complications such as delayed onset discogenic pain. ${ }^{31,32}$ Furthermore, authors of a recent meta-analysis reported that clinical outcomes and disc bulge will improve through nonsurgical treatment alone in more than half of $\mathrm{LDH}$ patients. ${ }^{33}$ On the other hand, the authors of the Maine Lumbar Spine Study reported that $31.2 \%$ of patients who underwent surgery and $40.1 \%$ who received nonsurgical treatment had persisting LBP after a 10 -year follow up. ${ }^{31}$ Similarly, Parker et al $^{32}$ showed that $32 \%$ of patients who underwent single- 
level discectomy for LDH and radiculopathy exhibited moderate to severe back pain after a 3year follow up. Due to the high prevalence rate of long-term discogenic pain, regenerative therapies such as stem-cell injections have recently been gaining popularity. ${ }^{34}$

One of the main complications after lumbar disc surgery is reherniation. Authors of a systematic review in 2015 based on 28 studies involving 6255 patients showed that reherniation rates may be as high as $23 \%$ after surgical treatment. ${ }^{35}$ Moreover, authors of several multicenter studies worldwide have shown that the cumulative risk of reoperation is around $20 \%$ in a 10 -year follow-up period. ${ }^{36,37}$ The patient-reported satisfaction rate is significantly lower after recurrent LDH surgery than outcomes after primary operation (58\% versus $79 \%) .{ }^{38}$ Miller et $\mathrm{al}^{39}$ demonstrated that patients with large $(>6$ $\mathrm{mm})$ annular tears after lumbar discectomy are more likely to have symptom recurrence (odds ratio $[\mathrm{OR}]=2.5)$ and reoperation $(\mathrm{OR}=2.3)$ than those who have small annular tears $(<6 \mathrm{~mm})$. Therefore, the innovative tissue-engineered annular repair approaches offer a promising solution to the prevention of reherniation and further degeneration in $\mathrm{LDH}$ patients. ${ }^{7,9,10}$

\section{Anatomy of the IVD}

The human IVD is a complex organ composed of fibrous and cartilaginous connective tissues that serves as a boundary between 2 adjacent vertebrae. It provides a limited range of motion in the torso as well as stability during axial compression, rotation, and bending. ${ }^{15}$ The IVD comprises anatomically distinct yet synergistic structures: the gelatinous NP, the concentric layers of fibrocartilaginous AF surrounding the NP core, and 2 vertebral endplates (VEPs) covering the entire superior and inferior surfaces of the $\operatorname{disc}^{40}$ (Figure 2). During the early stages of development, the notochord and mesodermal somites give rise to the structures of the IVD. ${ }^{15}$ However, the notochordal cells are replaced almost entirely by round chondrocyte-like cells in the NP beyond the first 10 years of life. ${ }^{41}$ This, in addition to the avascular nature of a mature IVD, possibly limits a disc's ability to self-regenerate ${ }^{42}$ (Figure 3).

The highly hydrated gel-like NP core is mainly composed of Type II collagen that acts as a mesh in which matrix elements such as aggrecan, hyaluronic acid, and other molecules are entrapped. ${ }^{43}$ Aggrecan is the most abundant proteoglycan (PG) in NP, and

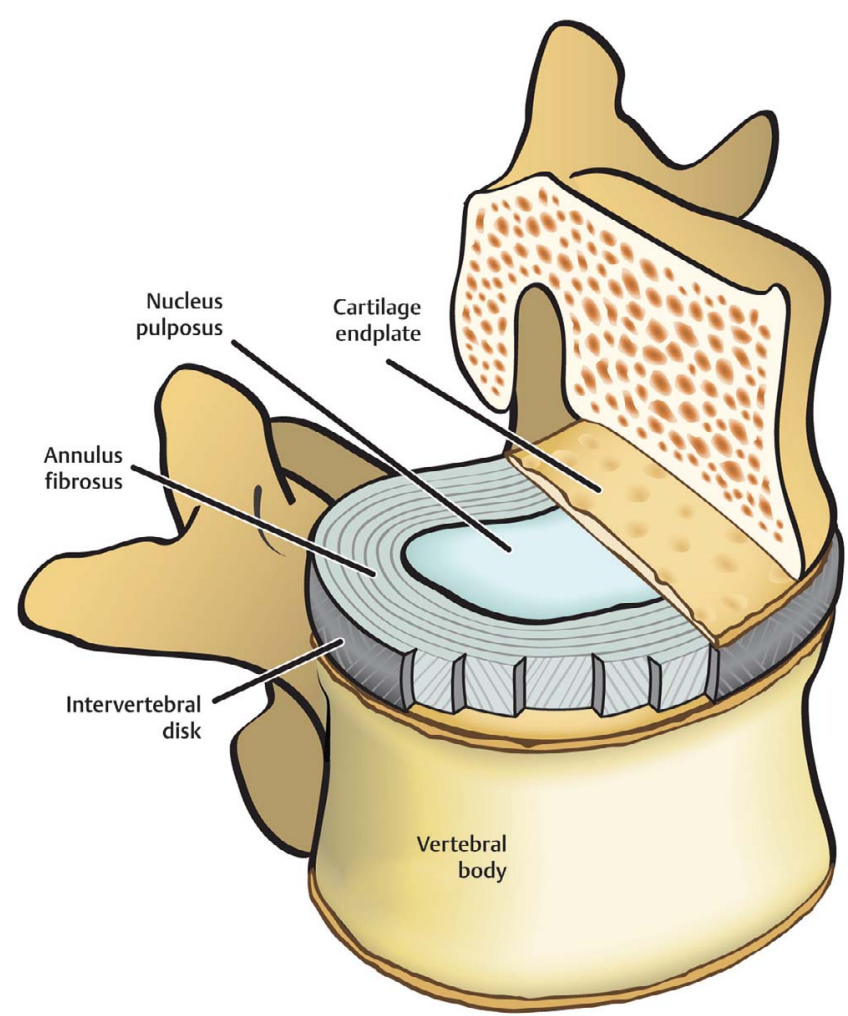

Figure 2. Anatomical composition of the human intervertebral disc. Centrally located nucleus pulposus and concentric organization of annulus fibrosus lamellae surrounding the periphery. Superiorly and inferiorly cover by cartilaginous endplate. Printed with permission from Biological Approaches to Spinal Disc Repair and Regeneration for Clinicians. ${ }^{15}$

it contains numerous glycosaminoglycan (GAG) chains that attract water within its network ${ }^{44,45}$ (Figure 4). Water retention in turn generates a swelling pressure that endows the NP its ability to resist compressive loads and maintain disc height ${ }^{45}$ (Figure 5). Aggrecan is highly concentrated within the center of the NP and diminishes radially outward. ${ }^{44}$ Furthermore, several studies ${ }^{46,47}$ revealed that the predominantly aneural nature of a mature and healthy IVD is attributed to a high concentration of aggrecan, the negatively charged moieties of which play a key role in preventing nerve ingrowth into the IVD.

Surrounding the NP core is the fibrocartilaginous $\mathrm{AF}$, and its matrix composition varies by region. ${ }^{48}$ The inner AF region has a composition like the NP, since it consists mainly of Type II collagen and aggrecans $^{49}$ (Figure 4). In fetal and juvenile discs, the delineation between the AF and NP regions is clear. $^{50}$ In adult discs, however, the outer NP transitions smoothly into the inner AF, making the boundary between the 2 regions indiscernible due to their similar matrix compositions. In contrast to the round chondrocyte-like cells of the mature 


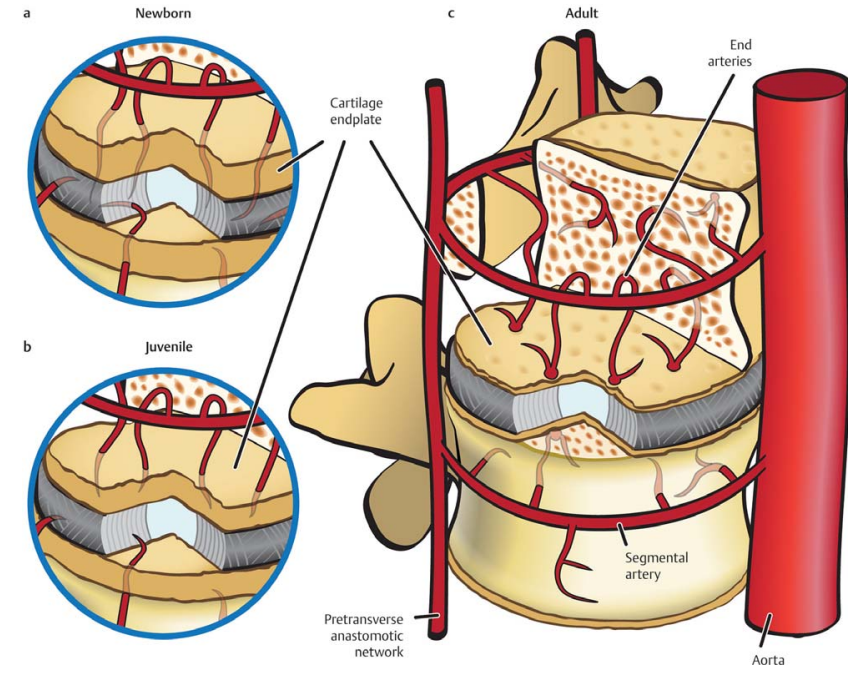

Figure 3. (a) Neonate's vertebral body and disc vascular network; blood supply can extend into the innermost regions of the annulus fibrosis (AF). (b) Vessels retract further from the disc to the outer region of the AF during adolescence. (c) Vessels are regressed further away from the AF and fix themselves within and surrounding the end plate and connective tissues in adult spines. Printed with permission from Biological Approaches to Spinal Disc Repair and Regeneration for Clinicians. ${ }^{15}$

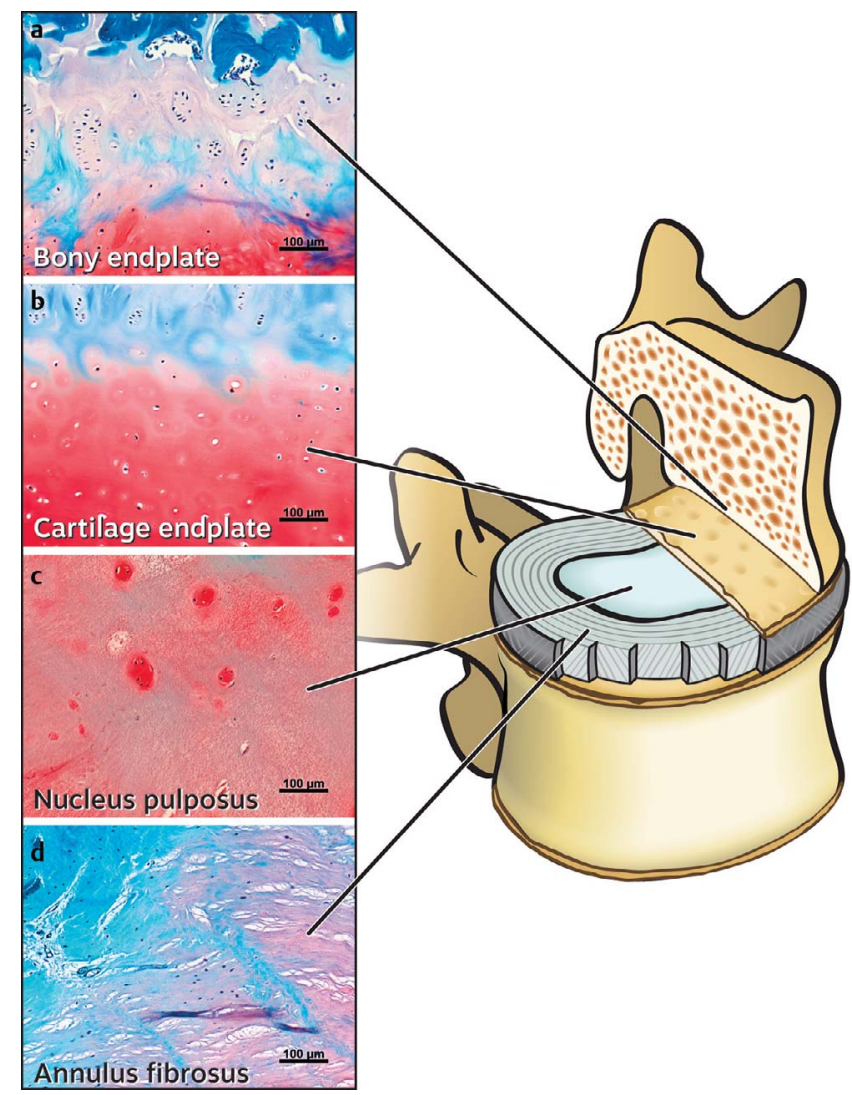

Figure 4. Histology images of human intervertebral disc. (a) and (b) Bony and cartilaginous endplates of a young healthy patient. The bony endplate is distinct and contains hypertrophic cartilage. (c) and (d) The nucleus pulpous (NP) and annulus fibrosus (AF). Histology stains were Safranin-O, fast green FCF, and Weigert's hematoxylin. Printed with permission from Biological Approaches to Spinal Disc Repair and Regeneration for Clinicians. ${ }^{15}$

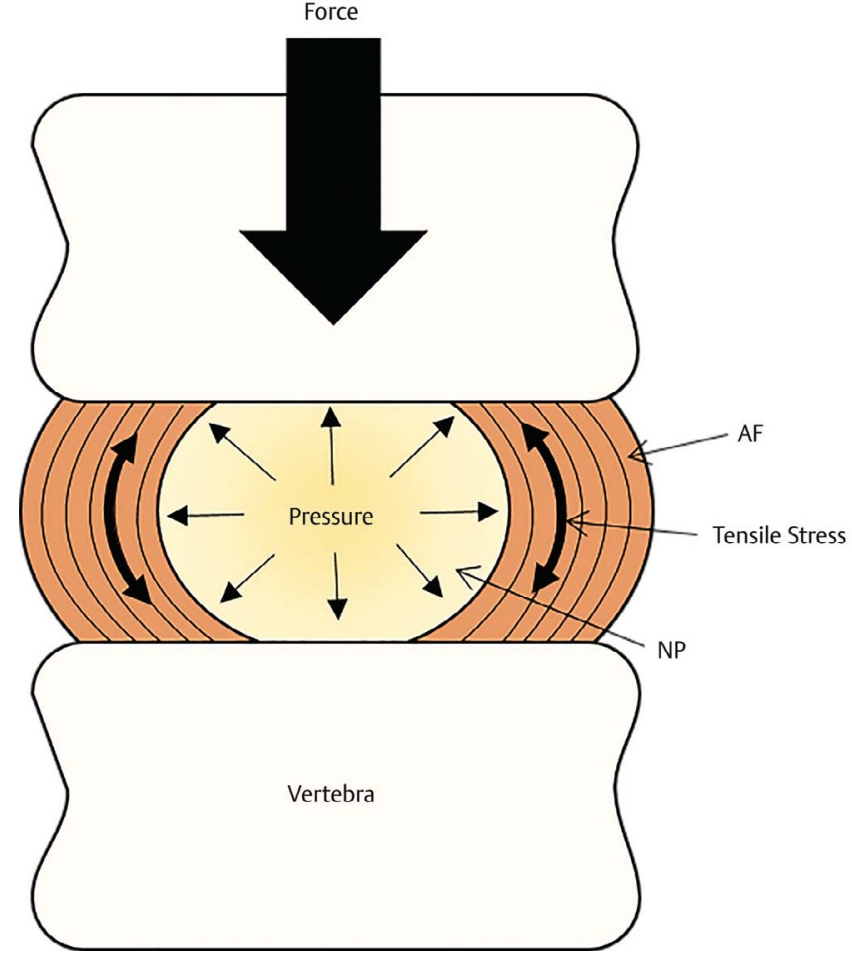

Figure 5. The intervertebral disc (IVD) undergoes load bearing, bending flexing, and torsion while under mechanical stressors. The annulus fibrosus (AF) and the nucleus pulposus (NP) form the IVD within the intervertebral space to fill the joint and maintain disc height. When the IVD is undergoes the previously mentioned physical stress, then the NP reacts by resisting the downward force against it by pressing vertically back into the compression and radially into the AF. The pressure from the NP generates tensile stress on the AF in the direction of the organization of the fibers within the AF. Printed with permission from Biological Approaches to Spinal Disc Repair and Regeneration for Clinicians. ${ }^{15}$

outer NP and inner AF, the cells found in the outer AF layers are elliptic and fibroblast-like. ${ }^{43}$ The composition of the outer AF layer is mostly of parallel collagen Type I fibers arranged in concentric lamellae and are oriented obliquely by about $30^{\circ}$ with respect to the longitudinal axis of the spine..$^{51,52}$ Moreover, these fibers form an angle-ply structure by alternating the direction of fibers between successive lamellae. ${ }^{42,52}$ The tensile strength contributed by this structure provides the AF its resilience to omnidirectional forces, thereby preventing NP content leakage during axial compression. $^{53}$

Lining the superior and inferior surfaces of both the NP and AF are the VEPs, which consist of 2 distinct layers: the cartilage endplate (CEP) composed of Type II collagen and aggrecan, as well as the bony endplate composed of cortical bone (Figure 4). The CEP portions of healthy VEPs have a thickness that is uniform and does not infiltrate the adjacent vertebra. ${ }^{54,55}$ Compared to the $27: 1$ PG-to-collagen ratio of the NP, the ratio is $2: 1$ such 
as in the hyaline cartilage of the CEP. ${ }^{56}$ VEPs serve 2 functions: one is to provide an attachment between the disc and vertebra, and the other is to provide a route for material transport to the disc. Vascularity is limited to the periphery of the CEP; therefore, nutrients and oxygen ultimately reach the $\mathrm{AF}$ and NP regions through passive diffusion. ${ }^{57}$

A healthy IVD is largely aneural, except for the outer AF layers innervated by sensory and sympathetic perivascular nerve fibers ${ }^{42}$ (Figure 6). Neoinnervation extending into the inner IVD thus provides a clear distinction between healthy and degenerated discs. Due to the absence of immune cells residing within the IVD, ${ }^{58}$ this implicates a good candidacy of degenerated IVDs for cell-based biological treatments. Furthermore, animal models for DDD research are required to exhibit loss of notochordal cells like in human IVDs. ${ }^{59} \mathrm{NP}$ notochordal cells are generally retained throughout life in most animals, except for a limited number of species such as cattle and sheep. ${ }^{30}$

\section{Pathophysiology of DDD}

DDD generally arises from the disruption of the homeostasis maintained by the structures of the IVD, and genetic and environmental factors can accelerate the progression of the disease. ${ }^{42,60} \mathrm{Au}$ thors of multiple studies have identified several risk factors linked to DDD such as genetics, ${ }^{61}$ obesity, ${ }^{62}$ smoking, ${ }^{63}$ and aging ${ }^{64}$; although the impact of each risk factor on the DDD progression is still unclear. Authors of a review in 2008 have demonstrated 34\% to $61 \%$ heritability rates of DDD and suggested that the complex inheritance pattern is associated with multiple genes. ${ }^{61}$ Furthermore, polymorphisms in the growth differentiation factor $5,{ }^{65}$ vitamin D receptor, ${ }^{66}$ and matrix degradative protease ${ }^{67}$ genes among others have been linked to IVD, although the extent of each gene's influence on the disease is still unknown. Mutations in the genes encoding for Type II collagen - a major component of the NP and inner AF extracellular matrix (ECM)-as well as Type XI collagen are found to be more related to spinal deformations involving the VEPs but not to DDD. ${ }^{68,69}$ On the other hand, polymorphisms on the COL1A1 (Type I collagen) genes have been linked to DDD by authors of multiple studies. ${ }^{70-72}$ Moreover, Solovieva et $\mathrm{al}^{73}$ implied that sequence variations in the collagen type IX (COL9A3) in conjunction with obesity increases DDD severity, as shown by reduced disc heights and lowered intensity

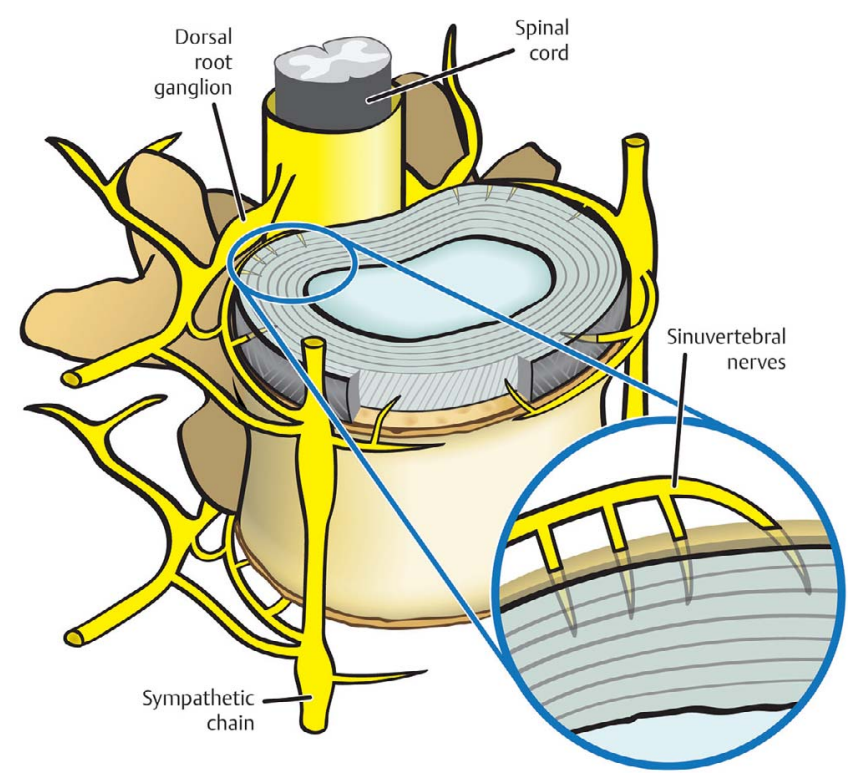

Figure 6. The sinuvertebral nerve innervates the disc. In a healthy adult disc, the nerve endings cannot reach into the innermost layers of the annulus fibrosus (AF). Printed with permission from Biological Approaches to Spinal Disc Repair and Regeneration for Clinicians. ${ }^{15}$

of MRI signals of the NP (black disc). Furthermore, polymorphisms in aggrecan genes are also linked to DDD: these sequence variations affect the lengths of the aggrecan core proteins as well as the number of chondroitin sulfate (CS) chains bound to aggrecan. ${ }^{74-76}$ A lower number of CS chains compromises the ability of the NP to retain water, leading to reduced disc height and improved conditions for neoinnervation. ${ }^{46,77}$

Other significant risk factors associated with DDD are obesity, smoking, and aging. In a population-based study, Samartzis et $\mathrm{al}^{78}$ on juveniles of ages 13 to 20 have shown that overweight and obese individuals showed a significantly higher severity of DDD than underweight and normal body mass index (BMI) individuals. Excessive compressive forces are exerted on the discs of overweight and obese individuals, making the discs more susceptible to early wear and tear and exacerbation of preexisting DDD. ${ }^{79}$ Moreover, being overweight or obese is a disorder in which inflammation is associated with increased serum levels of IL-6, C-reactive protein, TNF- $\alpha$, and leptin. $^{79}$ Inflammation in the IVD tissues often leads to a cascade of catabolic processes in the disc associated with DDD onset. ${ }^{42,80}$ Authors of several studies ${ }^{63,81}$ have implicated the risk of smoking for DDD, and the most accepted rationale for this association so far is that poor nutrition of spinal disc cells occurs via carboxy-hemoglobin-induced 
anoxia. $^{82}$ Moreover, Akmal et $\mathrm{al}^{63}$ showed that bovine NP disc cells cultured in vitro with nicotine concentrations of 100,200 , and $300 \mathrm{nmol} / \mathrm{L}$ after 21 days exhibited significant dose-dependent lowering of IVD cell proliferation and synthesis of ECM. They also found that there was a shift in NP ECM composition from Type II collagen to Type I. ${ }^{63}$ Authors of another study suggest the role of smoking as a significant risk factor for the onset of DDD since lowering the cell density of the NP in murine models and alteration of its matrix composition may lead to premature degeneration of an IVD. $^{81}$

Aging is a natural process during which an organism accumulates molecular and cellular damage over time. Compared with other types of tissues, IVDs can exhibit age-related degeneration as early as the second decade of life. This is mainly attributed to the loss of notochordal cells in the NP that are associated with anabolic activities in the cell such as enhancing cell proliferation and ECM synthesis, upregulating growth factors, and downregulating matrix metalloproteinase (MMP) expression. ${ }^{83}$ During the early onset of DDD, increased Type II collagen production is observed in the NP possibly as an attempt to self-repair. ${ }^{42}$ As disease progression continues, production of Type I collagen increases significantly as Type II collagen synthesis declines. ${ }^{84}$ This shift in collagen types in the NP and inner AF is accompanied by a decrease in aggrecan content, which results in loss of hydration and turgor pressure in the disc. ${ }^{42,43,84}$ These changes in the ECM of the NP thereby decrease disc height and induce fibrosis, negatively impacting its resilience to axial loading. ${ }^{85}$ Furthermore, changes in the ECM of the outer AF involve a slight increase in Type II collagen, which compromises its ability to contain the NP during axial compression. ${ }^{86}$ Excessive forces on the weakened outer AF lamellae eventually lead to formation of cracks and fissures, which increase the likelihood of NP material leaking into the outer AF. Furthermore, these defects in the outer AF of the degenerated disc consequently allow for neoinnervation and angiogenesis within the IVD.

Vascularization is only present as deep as the outer AF in a mature and healthy IVD, leaving the rest of the disc largely avascular. ${ }^{87}$ The inside of the disc therefore receives oxygen and nutrients via passive diffusion. ${ }^{88}$ Authors of recent studies ${ }^{89,90}$ have shown that, in degenerated IVDs, increased porosity of the endplate and trabeculae is associated with decreased nutrient transport to the disc in conjunction with endplate calcification. ${ }^{91}$ Inefficient nutrient transport to the disc induces a deleterious milieu characterized by an inadequate amount of oxygen and a buildup of lactic acid since the disc primarily derives its energy via glycolysis. ${ }^{92}$ Moreover, a drastic increase in acidity is linked to increased senescence and apoptosis of disc cells, ${ }^{93}$ while moderate $\mathrm{pH}$ changes affect metabolism of the IVD cells. ${ }^{94}$ Impaired cell metabolism due to $\mathrm{pH}$ alteration and poor nutrition (low supply and high demand) may also lead to autophagy and disruption of the homeostasis maintained by the IVD and thus plays a key role in DDD etiology. ${ }^{95}$ Derby et al ${ }^{96}$ also concluded that loss of PG induces neovascularization to compensate for the low supply and high metabolic demand in the disc. Authors of multiple studies have also established that the secretion of nerve growth factors and brain-derived neurotrophic factor by invading immune cells in the disc enhance fibroblast activity, neoinnervation, and angiogenesis in the IVD. ${ }^{97-99}$

Innervation inside a healthy IVD is absent due to the negatively charged CS chains of aggrecan which have been shown to inhibit neoinnervation within the disc. ${ }^{46}$ Consequently, loss of aggrecan in the NP and inner $\mathrm{AF}$ in conjunction with the loss of structural integrity of the outer AF layer both induce favorable conditions for growth of nociceptive and a few proprioceptive nerve fibers accompanied by angiogenesis in the disc. ${ }^{100}$ Furthermore, evidence from a study by Brown et al ${ }^{101}$ has shown that Substance $\mathrm{P}$ - a neuropeptide involved in regulating the perception of pain - is found to be overexpressed in degenerated IVDs. These transformations in the disc morphology, genetics, as well as the inflammatory milieu induced by the release of cytokines by native disc and invading immune cells are believed to cause discogenic pain ${ }^{102,103}$ (Figures 7 and 8).

Authors of multiple studies have established that cytokines and chemokines are present in large quantities in discs showing varying degrees of degeneration as well as in herniated discs. ${ }^{104-106}$ Nutrient-deprived resident IVD cells secrete chemokines that attract immune cells such as T- and Bcells, macrophages, and neutrophils to the once immune-privileged IVD. ${ }^{106}$ These immune cells further enhance the expression of pro-inflammatory cytokines such as TNF- $\alpha$ and IL-1 $\beta$; these 2 


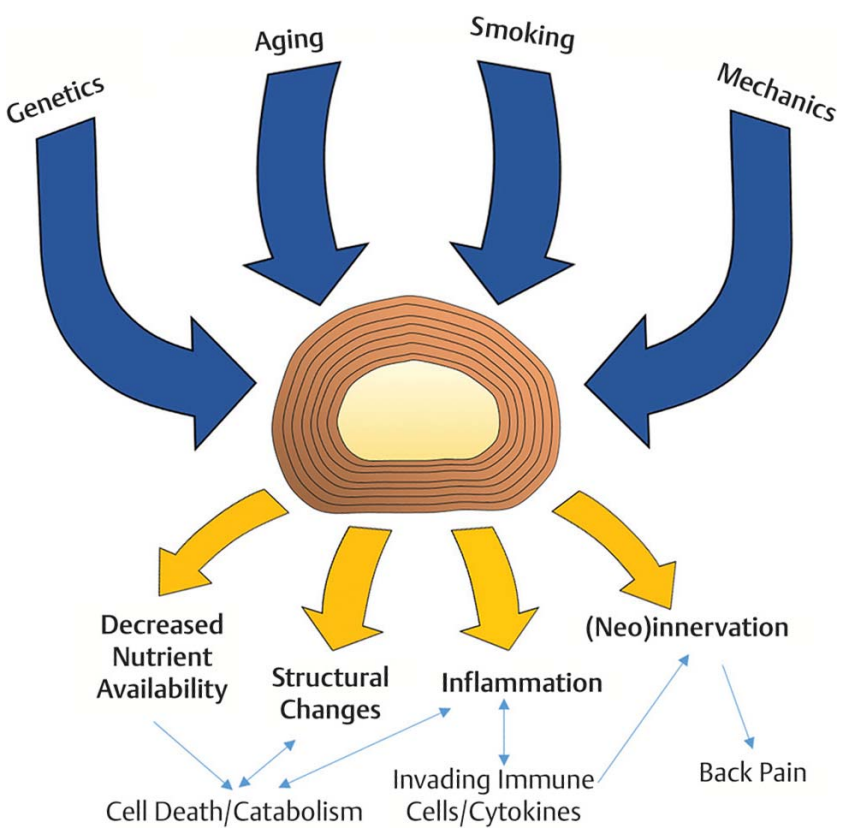

Figure 7. Degenerative disc disease (DDD) in a cascading multifactorial process involving the interaction of risk factors and pathophysiology. Printed with permission from Biological Approaches to Spinal Disc Repair and Regeneration for Clinicians. ${ }^{186}$

cytokines among others associated with DDD have been studied extensively and found to induce inflammation and cell apoptosis. ${ }^{107,108}$ TNFR1 and IL1R1 signaling is believed to induce the activation of the transcription factor $\mathrm{NF}-\kappa \mathrm{B} .{ }^{109}$ Activation of NF- $\kappa \mathrm{B}$ in turn induces the expression of genes associated with tissue and ECM degradation such as aggrecanases and MMPs in the IVD. ${ }^{110}$ Authors of a study conducted on degenerated rodent IVDs in vitro showed that inhibiting NF$\kappa \mathrm{B}$ activity lowered the expression of several MMP genes and thus slowed the progression of the degenerative process in the discs. ${ }^{111,112}$ In addition to upregulation of matrix degradative enzymes, NF$\kappa \mathrm{B}$ activity also enhances the expression of some pro-inflammatory genes in the disc, thereby upregulating the expression of several MMPs and aggrecanases that degrade collagen Type II and aggrecan in the NP and inner AF. ${ }^{13,114}$ This positive feedback loop perpetuates the deleterious environment within the disc, subjecting the IVD to further degeneration over time.

\section{Radiological Analyses of Healthy and Diseased Discs}

DDD is characterized by biochemical and structural alterations of the IVD under physiological and pathological stresses. ${ }^{115}$ MRI is a crucial noninva-

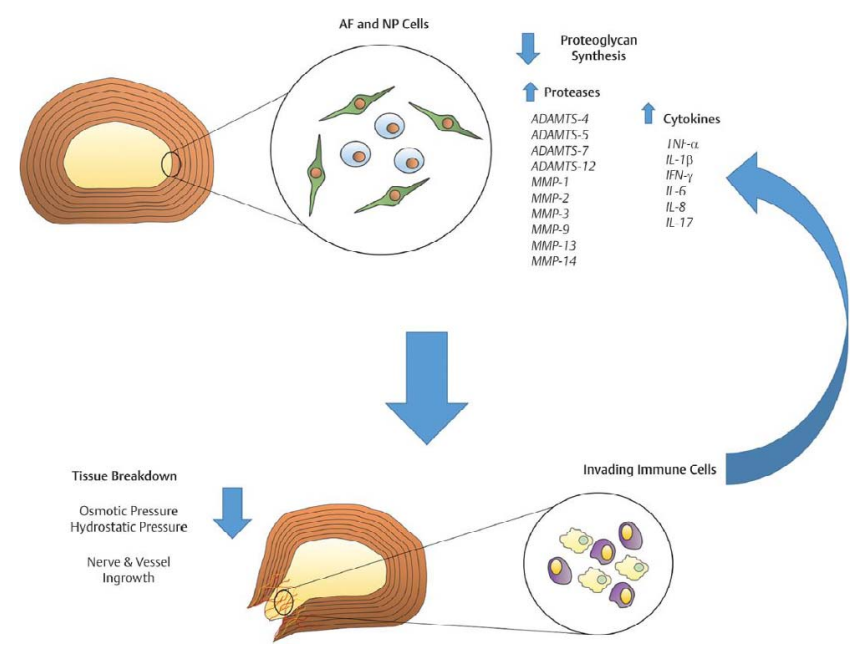

Figure 8. The physiological alterations to the disc are controlled directly by cells within the disc, which are caught in a closed degenerative cycle. These cells increase production of cytokines and proteases while decreasing production of proteoglycans, both of which are essential to the retaining the disc's height as well as maintaining the basic physical function of the intervertebral disc. The increase of proteases expedites the tissue degeneration process. The proteases also alter the extracellular environment, which incurs catabolic reaction and inflammation. This process results in the activation of nearby immune cells that exacerbates the inflammatory processes by continuing to increase cytokine production. The increase in cytokines enhances neovascularization and neoinnervation in the disc. Printed with permission from Biological Approaches to Spinal Disc Repair and Regeneration for Clinicians. ${ }^{186}$

sive method of IVD assessment, allowing for detection of collagen degradation, proteoglycan depletion, and other potential pain generating defects of the IVD. ${ }^{115}$ Effectively interpreting these images requires an understanding of the endogenous disc and endplate morphology, as visualized and quantified in MRI. ${ }^{116}$ Methods of consistent and reliable disc assessment are necessary for accurate inter-and intra-institutional communication, providing methods for diagnosis and future elucidation of disease pathogenesis. ${ }^{115}$

Discography, radiography, and computed tomography myelography have all previously been used to image discogenic pain. MRI, however, provides a method of direct multiplanar imaging with high-contrast resolution and lacks ionizing radiation. ${ }^{117}$ Thus, MRI has become increasingly prominent as a method of evaluation for disc degeneration. Biochemical and structural alterations of the IVD are pathognomonic of DDD, including alterations in water, collagen, and aggrecan-proteoglycan-GAG content, 3 of the major biochemical constituents in disc degeneration. ${ }^{118}$ MRI analysis is especially applicable in this regard. $\mathrm{T} 1-\rho$ is the time parameter of MRI relaxation, sensitive to lowfrequency interactions between macromolecules, providing visualization of proteoglycan matrix 
within the NP of the IVD. ${ }^{119} \mathrm{~T} 1-\rho$ relaxation times have been observed to have a positive correlation with GAG content, providing insight into the mechanical properties of the IVD, such as swelling pressure. ${ }^{119}$ T2 mapping correlates strongly with water content and, subsequently, with proteoglycan content. ${ }^{120}$ Degradation of these biochemical components may lead to fibrocartilage formation and annular disruption, perpetuating disc degeneration. ${ }^{118}$ Thus, visualizing these constituents through T2 mapping may provide a greater understanding of disc degeneration. ${ }^{121}$ Pfirrmann et a1 ${ }^{122}$ provided a widely accepted scale for assigning quantitative values to qualitative features present in T2 MRI of the human IVD (Figure 9). This scale has been used clinically in association with T2 values for both diagnostic and investigative purposes. ${ }^{122}$ Analyzing $\mathrm{T} 1$ in relation to $\mathrm{T} 2$ intensity may elucidate the health of the endplate, the subchondral bone underlying the IVD. ${ }^{118}$ Ultra-short TE MRI techniques have also been shown to be useful in investigating the health of the cartilaginous endplate. ${ }^{116}$ The classification of endplate damage may be indicative of underlying disorders of the adjacent IVD. In the future, ultrashort echo time (UTE) and diffusion weighted imaging (DWI) methods may be further advanced to provide information on the microstructure of the IVD and cartilaginous endplate, potentially showing collagen fiber alignment as it relates to DDD. ${ }^{118}$

MRI is also beneficial in analyzing the effectiveness of preclinical treatment methods of animal models. Typically, animal models are established due to similarities in morphology, physiology, or biomechanical features to that of the human IVD. MRI provides a noninvasive method for evaluating structural and biochemical commonalities between animal models and precedes methods for assessing the effectiveness of treatment methods applied to these models. MRI analysis has proven valuable in visualizing disc degeneration in preclinical models; however, interspecies variation in IVD structure and imaging characteristics calls to question the validity of the use of human-specific grading scales, such as the Pfirrmann grading scale. ${ }^{122}$ For this reason, future work must be performed to create valid measures of assessing MRIs of model IVDs.

MRI provides a method for detailed visualization of the endogenous IVD. Though MRI has yet to be reliably correlated to symptomology, key characteristics of degenerated discs have been assessed
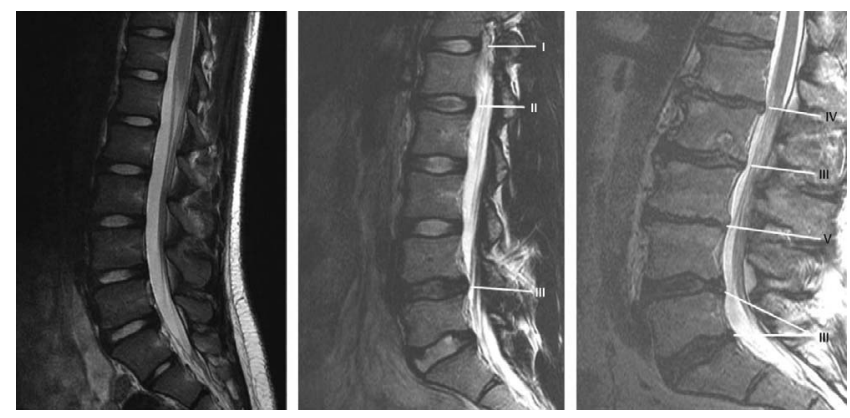

Figure 9. T2-weighted sagittal magnetic resonance images of three different patients. Roman numerals present the Pfirrmann grades. (Left) A female adolescent patient with healthy discs, (center) a young adult female patient with mild disc degeneration, and (right) a senior male patient with advanced disc degeneration. Printed with permission from Biological Approaches to Spinal Disc Repair and Regeneration for Clinicians. ${ }^{115}$

through various MRI modalities, allowing for qualitative and quantitative evaluation of biochemical and structural degeneration within the IVD. ${ }^{115,116,118}$ Advancing this noninvasive method of analysis and enhancing physician interpretation of the resulting images may provide a robust foundation for understanding and diagnosing DDD.

\section{Biomechanics of Healthy and Diseased Discs}

One of the primary functions of the IVD is to resist compression while limiting or enhancing flexibility based on the magnitude of the loads to which the spine is subjected, thereby ensuring even distribution of the loads across the vertebral bodies while maintaining their mobility. ${ }^{43,123,124}$ The disc's complex structure - ie, the presence of the waterand proteoglycan-rich NP and the highly oriented AF - contributes directly to its ability to act as a "cushion" for the spine, sustaining loads while functioning as a shock absorber. ${ }^{43,125}$

In a healthy disc, the high water content of the NP results in a buildup of hydrostatic pressure, which increases as a result of compressive loading. ${ }^{126,127}$ This pressurization in turn generates tension in the surrounding AF and results in outward bulging. ${ }^{43,128}$ Proteoglycans in the NP trap water and cause the tissue to swell as a result, balanced by the tensile forces distributed to the AF, until the tissue achieves equilibrium. ${ }^{43}$ The complex translamellar arrangement of fibers throughout the AF enables the development of tensile and circumferential stresses in response to the pressure buildup in the NP, while simultaneously providing resistance to shear between adjacent lamellae. ${ }^{129-132}$ As a result, the AF is loaded primarily in tension in 
response to typical loading conditions. Meanwhile, the outer region of the AF, composed of lamellae approximately 2 to 3 times stiffer than those at its interior, acts as a boundary in conjunction with the endplates to contain the NP as it swells. ${ }^{52,133,134}$ As the applied loads are removed, the pressure in the NP stabilizes, restoring normal disc height and allowing the disc to return to its equilibrium state.

As the disc matures and the process of degeneration unfolds, the disc undergoes a combination of structural and compositional changes (disc height loss, depletion of endogenous cell population, sclerosis, loss of AF-NP boundary, etc). ${ }^{135-138}$ The highest degree of degenerative change occurs in the NP, which becomes less gel-like and instead becomes stiffer and less compliant. ${ }^{139-141}$ As the disc degenerates, the biochemical content of the degenerated NP matrix shifts from proteoglycanrich Type II collagen toward a more fibrous Type I collagen. ${ }^{142}$ This depletion of proteoglycan content leads to an inability to bind water, rendering the NP increasingly unable to hydrate and potentially altering the viscoelastic behavior of the disc as a whole. ${ }^{143}$ The AF meanwhile thickens with degeneration, the fiber network becoming highly disorganized with progression, though these changes are not as well understood. ${ }^{135,139}$

With these alterations come direct consequences to the disc's mechanical response to loading. Rather than behaving as a fluid, as is the case in a healthy disc, the degenerated NP exhibits more solid-like behavior, ${ }^{144}$ while the AF begins to function as the sole compressive resistance. ${ }^{43}$ The NP's inability to hydrate results in a loss of pressurization ${ }^{124}$ and swelling capability, therefore rendering the disc unable to sustain and redistribute loads. Rate of recovery after loading is also significantly impaired in degenerated discs, as are disc height, motion segment flexibility, and overall axial compliance. ${ }^{139,145,146}$ Reduced pressure leads to decreased tension in the AF portion after compression, as well as increased shear stresses in the disc as a whole. ${ }^{147}$ In the NP, these shear forces can directly contribute to remodeling of the ECM as well as elicit inflammatory responses from the cellular population. ${ }^{148-150}$ In the AF, reduced annular tension results in increased bulging of the AF, which further increases shear forces between adjacent lamellae and subsequently leads to tears (radial, circumferential, or rim lesions) and delamination or structural failure of the disc. ${ }^{143,151,152}$ In fact, the combination of elevated shear stress and separation of the annular lamellae is thought to be one of the major causes of failure propagation in the $\mathrm{AF}^{151,153,154}$ as well as an initiator in a proposed degenerative cascade affecting the entire IVD.

Reduced motion segment flexibility and axial compliance generated by the IVD degeneration might provoke collateral damages and lead to further spinal degeneration. Authors of previous studies have shown that patients with DDD often simultaneously have facet joint degeneration. ${ }^{155-158}$ While facet arthrosis and IVD degeneration are the most prevalent factors in chronic LBP, the sequential relationship between the 2 processes is not well defined. ${ }^{159-162}$ Both types of degeneration have been shown to restrict spinal motion which could increase the loading in both IVD and facet joint. ${ }^{163,164}$ However, further research is needed to clearly identify the relationship between the 2 degenerative processes. Overall, DDD is not an isolated phenomenon as such a disease can cause the degenerative cascade in the spine and ultimately impact quality of life through factors such as severity of pain. ${ }^{165}$

\section{Assessment and Quantification of IVD Mechanics}

The IVD has interesting yet intricate mechanical properties due to its unique composition and architecture. The NP has a relatively homogenous composition and is often thought to have isotropic mechanical properties. ${ }^{166-168}$ On the other hand, the AF has anisotropic mechanical properties due to the collagen fiber alignment, as previously stated. ${ }^{169}$ During axial compression, pressure increases in the NP due to the compression transfer to the AF as a hoop or circumferential stress. The collagen fiber alignment in the AF allows the IVD to stretch radially and effectively mitigate the stress generated by the compression. The oblique orientation of the collagen fibers also helps to support various other loading modes such as tension, bending, and torsion. ${ }^{170}$ In addition to anisotropy, the existence of water within the IVD adds another layer of complexity to its mechanical behavior. The interaction between the water and collagen fibers within the IVD creates poroelasticity where temporal mechanical behavior is observed due to water leaving or entering the structure. During DDD, these structures and the overall composition within the IVD which dictate its mechanical properties are disrupted, ultimately changing the mechanics. ${ }^{171}$ Multiple 
analysis methods have been applied to fully characterize and understand the effect of DDD on the IVD's mechanical properties.

\section{IVD Degeneration and Mechanics}

Both in vivo and in vitro mechanical analysis methods have been applied to fully characterize the differences in mechanical properties between healthy and degenerated IVDs. MRI has been used widely to analyze the mechanical properties of the IVD in vivo and is promising due to its noninvasive nature. Multiple techniques exist for the application of MRI, such as obtaining T1 $\rho$ relaxation time or T2* relaxation time. ${ }^{147,172,173}$ However, the basic principle of these analyses is the same and involves looking at the biochemical composition, particularly proteoglycan content, of the IVD. The resulting compositional data are then correlated with in vitro mechanical testing of motion segments. Authors of various studies have identified the relationship between relaxation time and multiple parameters such as bending stiffness and swelling pressure. In vivo analysis has indicated that as IVD degeneration continues, swelling pressure can decrease to about to $35 \%$ that of a healthy IVD, while bending stiffness can increase to more than twice a healthy value. ${ }^{174,175}$ These changes result in lower range of motion (ROM) for patients and decrease stability of the spinal segment. ${ }^{176,177}$ Despite its promise, MRI can only estimate the mechanical stability of each patient due to its empirical nature.

In vitro mechanical testing generally involves spinal motion segments and a testing frame where compression and multi-axial torsion can be applied. Using such a testing frame, multiple mechanical properties such as compressive modulus and bending and torsional stiffness can be studied. The healthy IVD has compressive modulus which ranges from 10 to $20 \mathrm{MPa}$, while the degenerated IVD possesses a decreased compressive modulus of 5 to $12 \mathrm{MPa} .{ }^{178,179}$ Torsional stiffness increases with degeneration: the healthy IVD has a torsional stiffness ranging from 700 to $1100 \mathrm{Nmm} /{ }^{\circ}$, while that of the degenerated IVD ranges from 600 to $1800 \mathrm{Nmm} /{ }^{\circ}{ }^{180}$ Interestingly, surgical intervention to treat degeneration has been shown to further worsen mechanical performance. ${ }^{181,182}$ These bulk mechanical analyses may give a false impression that stress is distributed evenly across the structure; however, authors of multiple studies have shown stress is spatially dependent. Under axial compres- sion, healthy IVDs have a relatively uniform stress distribution from anterior to posterior region. ${ }^{183}$ As degeneration continues, intradiscal pressure is reduced by $30 \%$ and the AF starts to carry more load than the NP. ${ }^{184}$ Furthermore, in the lumbar disc, the posterior AF appears to carry more load than the NP or anterior AF; however stress and load distribution within the IVD is poorly understood. ${ }^{183}$

The abundance of water within the IVD plays a critical role in the mechanical response of the structure. ${ }^{185}$ The fluid flow in and out of the system due to external load causes the IVD to display poroelastic or temporal mechanical behavior. Once external load is applied to the structure, fluid moves outward and back in when the load is removed. As degradation continues, the time for this process to occur triples, and recovered disc height is decreased. $^{179}$

\section{CONCLUSIONS}

LBP remains a prevalent and challenging problem to treat, often linking directly or indirectly to degenerative changes within IVDs. Disc degeneration usually arises from the disruption of homeostasis maintained by the anatomical components of the IVD. The degenerative cascade usually starts with degradation of the ECM, resulting in the loss of proteoglycans, water content, and ultimately, disc height. In addition, the release of cytokines from ECM breakdown upregulates the production of aggrecanases and proteases while promoting the inflammatory signal pathways. This vicious cycle leads to continuous degeneration and induces neovascularization and neoinnervation of the IVD. To develop regenerative therapies for degenerated discs, authors of future studies must aim to restore both anatomical and biomechanical properties of the IVDs.

\section{REFERENCES}

1. Hoy D, March L, Brooks P, et al. The global burden of low back pain: estimates from the Global Burden of Disease 2010 study. Ann Rheum Dis. 2014;73(6):968-974.

2. Hoy D, Brooks P, Blyth F, Buchbinder R. The epidemiology of low back pain. Best Prac Res Cl Rh. 2010;24(6):769-781.

3. Hooten WM, Cohen SP. Evaluation and treatment of low back pain: a clinically focused review for primary care specialists. Mayo Clin Proc. 2015;90(12):1699-1718.

4. Anderson DG, Tannoury C. Molecular pathogenic factors in symptomatic disc degeneration. Spine J. 2005;5(suppl 6):260s-266s. 
5. Zhang YG, Guo TM, Guo X, Wu SX. Clinical diagnosis for discogenic low back pain. Int J Biol Sci. 2009;5(7):647-658.

6. Zhao L, Manchikanti L, Kaye AD, Abd-Elsayed A. Treatment of discogenic low back pain: current treatment strategies and future options - a literature review. Curr Pain Headache Rep. 2019;23(11):86. doi:10.1007/s11916-019-0821-x

7. Hussain I, Sloan SR, Wipplinger C, et al. Mesenchymal stem cell-seeded high-density collagen gel for annular repair: 6week results from in vivo sheep models. Neurosurgery. 2019;85(2):E350-e359.

8. Jiang EY, Sloan SR, Jr., Wipplinger C, Kirnaz S, Härtl R, Bonassar LJ. Proteoglycan removal by chondroitinase ABC improves injectable collagen gel adhesion to annulus fibrosus. Acta Biomater. 2019;97(Oct):428-436.

9. Moriguchi Y, Borde B, Berlin C, et al. In vivo annular repair using high-density collagen gel seeded with annulus fibrosus cells. Acta Biomater. 2018;79(Oct):230-238.

10. Sloan SR, Jr., Wipplinger C. Combined nucleus pulposus augmentation and annulus fibrosus repair prevents acute intervertebral disc degeneration after discectomy. Sci Trans Med. 2020;12(534). doi:10.1126/scitranslmed.aay2380

11. Moriguchi Y, Alimi M, Khair T, et al. Biological treatment approaches for degenerative disk disease: a literature review of in vivo animal and clinical data. Sci Transl Med. 2016;6(5):497-518.

12. Sloan SR, Jr., Lintz M, Hussain I, Hartl R, Bonassar LJ. Biologic annulus fibrosus repair: a review of preclinical in vivo investigations. Tissue Eng. Part B Rev. 2018;24(3):179-190.

13. Kennon JC, Awad ME, Chutkan N, DeVine J, Fulzele S. Current insights on use of growth factors as therapy for intervertebral disc degeneration. Biomol Concepts. 2018;9(1):43-52.

14. Urits I, Capuco A, Sharma M, et al. Stem cell therapies for treatment of discogenic low back pain: a comprehensive review. Curr Pain Headache Rep. 2019;23(9):65. doi:10.1007/ s11916-019-0804-y

15. Gravel JT, Abduljabbar FH, Ouellet J, Haglund L. Chapter 1: The human spinal disc: relevant anatomy and physiology In: Härtl R, Bonassar LJ, eds. Biological Approaches to Spinal Disc Repair and Regeneration for Clinicians. New York: Thieme Medical Publishers; 2017:2-10.

16. Hoy D, Bain C, Williams G, et al. A systematic review of the global prevalence of low back pain. Arthritis Rheum. 2012;64(6):2028-2037.

17. Ravindra VM, Senglaub SS, Rattani A, et al. Degenerative lumbar spine disease: estimating global incidence and worldwide volume. Global Spine J. 2018;8(8):784-794.

18. Freburger JK, Holmes GM, Agans RP, et al. The rising prevalence of chronic low back pain. Arch Intern Med. 2009;169(3):251-258.

19. Puschmann AK, Drießlein D. Stress and self-efficacy as long-term predictors for chronic low back pain: a prospective longitudinal study. J Pain Res. 2020;13:613-621.

20. Halonen JI, Shiri R, Magnusson Hanson LL, Lallukka T. Risk and prognostic factors of low back pain: repeated population-based cohort study in Sweden. J Pain Res. 2019;44(17):1248-1255.

21. Øiestad BE, Hilde G, Tveter AT, et al. Risk factors for episodes of back pain in emerging adults. A systematic review. Eur J Pain. 2020;24(1):19-38.

22. Cecchi F, Debolini P, Lova RM, et al. Epidemiology of back pain in a representative cohort of Italian persons 65 years of age and older: the InCHIANTI study. Spine (Phila Pa 1976). 2006;31(10):1149-1155.

23. Pai S, Sundaram LJ. Low back pain: an economic assessment in the United States. Orthop Clin North Am. 2004;35(1):1-5.

24. McDermott KW, Freeman WJ, Elixhauser A. Overview of operating room procedures during inpatient stays in U.S. hospitals, 2014: statistical brief \#233. In: Healthcare Cost and Utilization Project (HCUP) Statistical Briefs. Rockville (MD): Agency for Healthcare Research and Quality (US); 2006.

25. Chang L KS, Del Castillo-Calcaneo J, Hussain I, Härtl R. Fundamentals of minimally invasive spine surgery. Indian Spine J. 2020;3(4):4-10.

26. Arts MP, Brand R, van den Akker ME, Koes BW, Bartels RH, Peul WC. Tubular diskectomy vs conventional microdiskectomy for sciatica: a randomized controlled trial. JAMA. 2009;302(2):149-158.

27. Cheung KM, Karppinen J, Chan D, et al. Prevalence and pattern of lumbar magnetic resonance imaging changes in a population study of one thousand forty-three individuals. Spine (Phila Pa 1976). 2009;34(9):934-940.

28. Padua R, Padua S, Romanini E, Padua L, de Santis E. Ten- to 15-year outcome of surgery for lumbar disc herniation: radiographic instability and clinical findings. Eur Spine $J$. 1999;8(1):70-74.

29. Simon J, McAuliffe M, Shamim F, Vuong N, Tahaei A. Discogenic low back pain. Phys Med Rehabil Clin $N \mathrm{Am}$. 2014;25(2):305-317.

30. Daly C, Ghosh P, Jenkin G. A review of animal models of intervertebral disc degeneration: pathophysiology, regeneration, and translation to the clinic. BioMed Res Int. 2016;2016:5952165. doi:10.1155/2016/5952165

31. Atlas SJ, Keller RB, Wu YA, Deyo RA, Singer DE. Long-term outcomes of surgical and nonsurgical management of sciatica secondary to a lumbar disc herniation: 10 year results from the Maine lumbar spine study. BioMed Res Int. 2005;30(8):927-935.

32. Parker SL, Xu R, McGirt MJ, Witham TF, Long DM, Bydon A. Long-term back pain after a single-level discectomy for radiculopathy: incidence and health care cost analysis. $J$ Neurosurg Spine. 2010;12(2):178-182.

33. Zhong $\mathrm{M}$, Liu JT, Jiang $\mathrm{H}$, et al. Incidence of spontaneous resorption of lumbar disc herniation: a metaanalysis. Pain Physician. 2017;20(1):e45-e52.

34. Chakravarthy K, Chen Y, He C, Christo PJ. Stem cell therapy for chronic pain management: review of uses, advances, and adverse effects. Pain Physician. 2017;20(4):293-305.

35. Parker SL, Mendenhall SK, Godil SS, et al. Incidence of low back pain after lumbar discectomy for herniated disc and its effect on patient-reported outcomes. Clin Orthop Relat Res. 2015;473(6):1988-1999.

36. Keskimäki I, Seitsalo S, Osterman H, Rissanen P. Reoperations after lumbar disc surgery: a population-based study of regional and interspecialty variations. Spine (Phila $\mathrm{Pa}$ 1976). 2000;25(12):1500-1508.

37. Martin BI, Mirza SK, Flum DR, et al. Repeat surgery after lumbar decompression for herniated disc: the quality implications of hospital and surgeon variation. Spine $J$. 2012;12(2):89-97.

38. Fritzell P, Knutsson B, Sanden B, Strömqvist B, Hägg O. Recurrent versus primary lumbar disc herniation surgery: 
patient-reported outcomes in the Swedish spine register Swespine. Clin Orthop Relat Res. 2015;473(6):1978-1984.

39. Miller LE, McGirt MJ, Garfin SR, Bono CM. Association of annular defect width after lumbar discectomy with risk of symptom recurrence and reoperation: systematic review and meta-analysis of comparative studies. Spine (Phila Pa 1976). 2018;43(5):e308-e315.

40. Raj PP. Intervertebral disc: anatomy-physiology-pathophysiology-treatment. Pain Pract. 2008;8(1):18-44.

41. Oichi T, Taniguchi Y, Oshima Y, Tanaka S, Saito T. Pathomechanism of intervertebral disc degeneration. JOR Spine. 2020;3(1):e1076. doi:10.1002/jsp2.1076

42. Navone SE, Marfia G, Giannoni A, et al. Inflammatory mediators and signalling pathways controlling intervertebral disc degeneration. Histol Histopathol. 2017;32(6):523-542.

43. Adams MA, Roughley PJ. What is intervertebral disc degeneration, and what causes it? Spine (Phila Pa 1976). 2006;31(18):2151-2161.

44. Kepler CK, Anderson DG, Tannoury C, Ponnappan RK. Intervertebral disk degeneration and emerging biologic treatments. J Am Acad Orthop Surg. 2011;19(9):543-553.

45. Freemont AJ. The cellular pathobiology of the degenerate intervertebral disc and discogenic back pain. Rheumatology (Oxford). 2009;48(1):5-10.

46. Johnson WE, Caterson B, Eisenstein SM, Hynds DL, Snow DM, Roberts S. Human intervertebral disc aggrecan inhibits nerve growth in vitro. Arthritis Rheum. 2002;46(10):2658-2664.

47. Purmessur D, Cornejo MC, Cho SK, et al. Intact glycosaminoglycans from intervertebral disc-derived notochordal cell-conditioned media inhibit neurite growth while maintaining neuronal cell viability. Spine J. 2015;15(5):10601069.

48. Humzah MD, Soames RW. Human intervertebral disc: structure and function. Anat Rec. 1988;220(4):337-356.

49. Kerr GJ, Veras MA, Kim MK, Séguin CA. Decoding the intervertebral disc: unravelling the complexities of cell phenotypes and pathways associated with degeneration and mechanotransduction. Semin Cell Dev Biol. 2017;62(Feb):94-103.

50. Sive JI, Baird P, Jeziorsk M, Watkins A, Hoyland JA, Freemont AJ. Expression of chondrocyte markers by cells of normal and degenerate intervertebral discs. Mol Pathol. 2002;55(2):91-97.

51. Marchand F, Ahmed AM. Investigation of the laminate structure of lumbar disc anulus fibrosus. Spine (Phila Pa 1976). 1990;15(5):402-410.

52. Skaggs DL, Weidenbaum M, Iatridis JC, Ratcliffe A, Mow VC. Regional variation in tensile properties and biochemical composition of the human lumbar anulus fibrosus. Spine (Phila Pa 1976). 1994;19(12):1310-1319.

53. Pezowicz CA, Robertson PA, Broom ND. Intralamellar relationships within the collagenous architecture of the annulus fibrosus imaged in its fully hydrated state. $J$ Anat. 2005;207(4):299-312.

54. Thompson JP, Pearce RH, Schechter MT, Adams ME, Tsang IK, Bishop PB. Preliminary evaluation of a scheme for grading the gross morphology of the human intervertebral disc. Spine (Phila Pa 1976). 1990;15(5):411-415.

55. Rutges JP, Duit RA, Kummer JA, et al. A validated new histological classification for intervertebral disc degeneration. Osteoarthr Cartil. 2013;21(12):2039-2047.

56. Mwale F, Roughley P, Antoniou J. Distinction between the extracellular matrix of the nucleus pulposus and hyaline cartilage: a requisite for tissue engineering of intervertebral disc. Eur Cells Mater. 2004;8:58-63; discussion 63-54. doi:10.22203/ ecm.v008a06

57. Urban JP, Smith S, Fairbank JC. Nutrition of the intervertebral disc. Spine (Phila Pa 1976). 2004;29(23):27002709.

58. Murai K, Sakai D, Nakamura Y, et al. Primary immune system responders to nucleus pulposus cells: evidence for immune response in disc herniation. Eur Cells Mater. 2010;19:13-21. doi:10.22203/eCM.v019a02

59. Colombier P, Clouet J, Hamel O, Lescaudron L, Guicheux J. The lumbar intervertebral disc: from embryonic development to degeneration. Joint Bone Spine. 2014;81(2):125129.

60. Virtanen IM, Karppinen J, Taimela S, et al. Occupational and genetic risk factors associated with intervertebral disc disease. Spine (Phila Pa 1976). 2007;32(10):1129-1134.

61. Kalichman L, Hunter DJ. The genetics of intervertebral disc degeneration. Familial predisposition and heritability estimation. Joint Bone Spine. 2008;75(4):383-387.

62. Shiri R, Karppinen J, Leino-Arjas P, Solovieva S, Viikari-Juntura E. The association between obesity and low back pain: a meta-analysis. Am J Epidemiol. 2010;171(2):135154.

63. Akmal M, Kesani A, Anand B, Singh A, Wiseman M, Goodship A. Effect of nicotine on spinal disc cells: a cellular mechanism for disc degeneration. Spine (Phila Pa 1976). 2004;29(5):568-575.

64. Wang F, Cai F, Shi R, Wang XH, Wu XT. Aging and age related stresses: a senescence mechanism of intervertebral disc degeneration. Osteoarthr Cartil. 2016;24(3):398-408.

65. Williams FM, Popham M, Hart DJ, et al. GDF5 singlenucleotide polymorphism rs143383 is associated with lumbar disc degeneration in Northern European women. Arthritis Rheum. 2011;63(3):708-712.

66. Kawaguchi Y, Kanamori M, Ishihara H, Ohmori K, Matsui H, Kimura T. The association of lumbar disc disease with vitamin-D receptor gene polymorphism. J Bone Joint Surg. 2002;84(11):2022-2028.

67. Zhang J, Sun X, Liu J, Liu J, Shen B, Nie L. The role of matrix metalloproteinase 14 polymorphisms in susceptibility to intervertebral disc degeneration in the Chinese Han population. Arch Med Sci. 2015;11(4):801-806.

68. Scapinelli R. Lumbar disc herniation in eight siblings with a positive family history for disc disease. Acta Orthop Belg. 1993;59(4):371-376.

69. Myllyharju J, Kivirikko KI. Collagens and collagenrelated diseases. Ann Med. 2001;33(1):7-21.

70. Toktaş ZO, Ekşi M, Yılmaz B, et al. Association of collagen I, IX and vitamin D receptor gene polymorphisms with radiological severity of intervertebral disc degeneration in Southern European ancestor. Eur Spine J. 2015;24(11):24322441.

71. Tilkeridis C, Bei T, Garantziotis S, Stratakis CA. Association of a COL1A1 polymorphism with lumbar disc disease in young military recruits. J Med Genet. 2005;42(7):e44. doi:10.1136/jmg.2005.033225

72. Videman T, Saarela J, Kaprio J, et al. Associations of 25 structural, degradative, and inflammatory candidate genes with lumbar disc desiccation, bulging, and height narrowing. Arthritis Rheum. 2009;60(2):470-481. 
73. Solovieva S, Lohiniva J, Leino-Arjas P, et al. COL9A3 gene polymorphism and obesity in intervertebral disc degeneration of the lumbar spine: evidence of gene-environment interaction. Spine (Phila Pa 1976). 2002;27(23):2691-2696.

74. Kawaguchi Y. Genetic background of degenerative disc disease in the lumbar spine. Spine Surg Relat Res. 2018;2(2):98112.

75. Cong L, Pang H, Xuan D, Tu GJ. Association between the expression of aggrecan and the distribution of aggrecan gene variable number of tandem repeats with symptomatic lumbar disc herniation in Chinese Han of Northern China. Spine (Phila Pa 1976). 2010;35(14):1371-1376.

76. Mashayekhi F, Shafiee G, Kazemi M, Dolati P. Lumbar disk degeneration disease and aggrecan gene polymorphism in northern Iran. Biochem Genet. 2010;48(7-8):684-689.

77. Kawaguchi Y, Osada R, Kanamori M, et al. Association between an aggrecan gene polymorphism and lumbar disc degeneration. Spine (Phila Pa 1976). 1999;24(23):2456-2460.

78. Samartzis D, Karppinen J, Mok F, Fong DY, Luk KD, Cheung KM. A population-based study of juvenile disc degeneration and its association with overweight and obesity, low back pain, and diminished functional status. $J$ Bone $J t$ Surg. 2011;93(7):662-670.

79. Samartzis D, Karppinen J, Cheung JP, Lotz J. Disk degeneration and low back pain: are they fat-related conditions? Global Spine J. 2013;3(3):133-144.

80. Feng C, Liu H, Yang M, Zhang Y, Huang B, Zhou Y. Disc cell senescence in intervertebral disc degeneration: causes and molecular pathways. Cell Cycle. 2016;15(13):1674-1684.

81. Wang D, Nasto LA, Roughley $\mathrm{P}$, et al. Spine degeneration in a murine model of chronic human tobacco smokers. Osteoarthr Cartil. 2012;20(8):896-905.

82. Cong L, Pang $\mathrm{H}$, Xuan $\mathrm{D}, \mathrm{Tu} \mathrm{G}$. The interaction between aggrecan gene VNTR polymorphism and cigarette smoking in predicting incident symptomatic intervertebral disc degeneration. Connect Tissue Res. 2010;51(5):397-403.

83. Risbud MV, Schaer TP, Shapiro IM. Toward an understanding of the role of notochordal cells in the adult intervertebral disc: from discord to accord. Dev Dyn. 2010;239(8):2141-2148.

84. Le Maitre CL, Pockert A, Buttle DJ, Freemont AJ, Hoyland JA. Matrix synthesis and degradation in human intervertebral disc degeneration. Biochem Soc Trans. 2007;35(Pt 4):652-655.

85. Johnstone B, Urban JP, Roberts S, Menage J. The fluid content of the human intervertebral disc. Comparison between fluid content and swelling pressure profiles of discs removed at surgery and those taken postmortem. Spine (Phila Pa 1976). 1992;17(4):412-416.

86. Yao CF, Zhao YJ, Niu K, et al. [Experimental study on lumbar intervertebral disc degeneration model with kidney deficiency by ovariectomizing]. Zhongguo Gu Shang. 2013;26(12):1015-1022.

87. Grunhagen T, Wilde G, Soukane DM, Shirazi-Adl SA, Urban JP. Nutrient supply and intervertebral disc metabolism. J Bone Jt Surg. 2006;88(suppl 2):30-35.

88. Urban JP, Holm S, Maroudas A, Nachemson A. Nutrition of the intervertebral disc: effect of fluid flow on solute transport. Clin Orthop Relat Res. 1982(170):296-302.

89. Rodriguez AG, Slichter CK, Acosta FL, et al. Human disc nucleus properties and vertebral endplate permeability. Spine (Phila Pa 1976). 2011;36(7):512-520.
90. Rodriguez AG, Rodriguez-Soto AE, Burghardt AJ, Berven S, Majumdar S, Lotz JC. Morphology of the human vertebral endplate. J Orthop Res. 2012;30(2):280-287.

91. Hashimoto S, Ochs RL, Rosen F, et al. Chondrocytederived apoptotic bodies and calcification of articular cartilage. Proc Natl Acad Sci U S A. 1998;95(6):3094-3099.

92. Grunhagen T, Shirazi-Adl A, Fairbank JC, Urban JP. Intervertebral disk nutrition: a review of factors influencing concentrations of nutrients and metabolites. Orthop Clin North Am. 2011;42(4):465-477, vii.

93. Horner HA, Urban JP. 2001 Volvo Award Winner in Basic Science Studies: effect of nutrient supply on the viability of cells from the nucleus pulposus of the intervertebral disc. Spine (Phila Pa 1976). 2001;26(23):2543-2549.

94. Ohshima H, Urban JP. The effect of lactate and $\mathrm{pH}$ on proteoglycan and protein synthesis rates in the intervertebral disc. Spine (Phila Pa 1976). 1992;17(9):1079-1082.

95. Zhang SJ, Yang W, Wang C, et al. Autophagy: A double-edged sword in intervertebral disk degeneration. Clin Chim Acta. 2016;457(Jun):27-35.

96. Derby R, Howard MW, Grant JM, Lettice JJ, Van Peteghem PK, Ryan DP. The ability of pressure-controlled discography to predict surgical and nonsurgical outcomes. Spine (Phila Pa 1976). 1999;24(4):364-371; discussion 371-362.

97. Navone SE, Marfia G, Canzi L, et al. Expression of neural and neurotrophic markers in nucleus pulposus cells isolated from degenerated intervertebral disc. J Orthop Res. 2012;30(9):1470-1477.

98. Purmessur D, Freemont AJ, Hoyland JA. Expression and regulation of neurotrophins in the nondegenerate and degenerate human intervertebral disc. Arthritis Res Ther. 2008;10(4):R99. doi:10.1186/ar2487

99. Kao TH, Peng YJ, Tsou HK, Salter DM, Lee HS. Nerve growth factor promotes expression of novel genes in intervertebral disc cells that regulate tissue degradation: laboratory investigation. J Neurosurg Spine. 2014;21(4):653-661.

100. Freemont AJ, Peacock TE, Goupille P, Hoyland JA, O'Brien J, Jayson MI. Nerve ingrowth into diseased intervertebral disc in chronic back pain. Lancet (London). 1997;350(9072):178-181.

101. Brown MF, Hukkanen MV, McCarthy ID, et al. Sensory and sympathetic innervation of the vertebral endplate in patients with degenerative disc disease. J Bone Jt Surg. 1997;79(1):147-153.

102. Kokubo Y, Uchida K, Kobayashi S, et al. Herniated and spondylotic intervertebral discs of the human cervical spine: histological and immunohistological findings in 500 en bloc surgical samples. Laboratory investigation. $J$ Neurosurg Spine. 2008;9(3):285-295.

103. Shen B, Melrose J, Ghosh P, Taylor F. Induction of matrix metalloproteinase-2 and -3 activity in ovine nucleus pulposus cells grown in three-dimensional agarose gel culture by interleukin-1beta: a potential pathway of disc degeneration. Eur Spine J. 2003;12(1):66-75.

104. Takahashi H, Suguro T, Okazima Y, Motegi M, Okada Y, Kakiuchi T. Inflammatory cytokines in the herniated disc of the lumbar spine. Spine (Phila Pa 1976). 1996;21(2):218-224.

105. Shamji MF, Setton LA, Jarvis W, et al. Proinflammatory cytokine expression profile in degenerated and herniated human intervertebral disc tissues. Arthritis Rheum. 2010;62(7):1974-1982.

106. Risbud MV, Shapiro IM. Role of cytokines in 
intervertebral disc degeneration: pain and disc content. Nat Rev Rheumatol. 2014;10(1):44-56.

107. Phillips KL, Cullen K, Chiverton N, et al. Potential roles of cytokines and chemokines in human intervertebral disc degeneration: interleukin-1 is a master regulator of catabolic processes. Osteoarthr Cartil. 2015;23(7):1165-1177.

108. Yang $\mathrm{W}, \mathrm{Yu} \mathrm{XH}$, Wang $\mathrm{C}$, et al. Interleukin-1 $\beta$ in intervertebral disk degeneration. Clin Chim Acta. 2015;450(Oct):262-272.

109. Wang C, Yu X, Yan Y, et al. Tumor necrosis factor- $\alpha$ : a key contributor to intervertebral disc degeneration. Acta Biochim Biophys Sin. 2017;49(1):1-13.

110. Wang WJ, Yu XH, Wang C, et al. MMPs and ADAMTSs in intervertebral disc degeneration. Clin Chim Acta. 2015;448(Aug):238-246.

111. Andrade P, Visser-Vandewalle V, Philippens M, et al. Tumor necrosis factor- $\alpha$ levels correlate with postoperative pain severity in lumbar disc hernia patients: opposite clinical effects between tumor necrosis factor receptor 1 and 2. Pain. 2011;152(11):2645-2652.

112. Nasto LA, Seo HY, Robinson AR, et al. ISSLS prize winner: inhibition of $\mathrm{NF}-\kappa \mathrm{B}$ activity ameliorates age-associated disc degeneration in a mouse model of accelerated aging. Spine (Phila Pa 1976). 2012;37(21):1819-1825.

113. Liang H, Yang X, Liu C, Sun Z, Wang X. Effect of NF$\mathrm{kB}$ signaling pathway on the expression of MIF, TNF- $\alpha$, IL-6 in the regulation of intervertebral disc degeneration. $J$ Musculoskelet Neuronal Interact. 2018;18(4):551-556.

114. Wang Z, Hutton WC, Yoon ST. Bone morphogenetic protein-7 antagonizes tumor necrosis factor- $\alpha$-induced activation of nuclear factor $\kappa \mathrm{B}$ and up-regulation of the ADAMTS, leading to decreased degradation of disc matrix macromolecules aggrecan and collagen II. Spine J. 2014;14(3):505-512.

115. Potter HG, Sneag DB. Chapter 3: Imaging of the healthy and diseased spinal disc. In: Härtl R, Bonassar LJ, eds. Biological Approaches to Spinal Disc Repair and Regeneration for Clinicians. New York: Thieme Medical Publishers; 2017:2029.

116. Ogon I, Takebayashi T, Takashima H, et al. Imaging diagnosis for intervertebral disc. JOR Spine. 2020;3(1):e1066. doi:10.1002/jsp2.1066

117. Saboeiro GR. Lumbar discography. Radiol Clin North Am. 2009;47(3):421-433.

118. Paul CPL, Smit TH, de Graaf M, et al. Quantitative MRI in early intervertebral disc degeneration: T1rho correlates better than T2 and ADC with biomechanics, histology and matrix content. PloS One. 2018;13(1):e0191442. doi:10.1371/ journal.pone.0191442

119. Zhou Z, Jiang B, Zhou Z, et al. Intervertebral disk degeneration: T1 $\rho$ MR imaging of human and animal models. Radiology. 2013;268(2):492-500.

120. Marinelli NL, Haughton VM, Muñoz A, Anderson PA. T2 relaxation times of intervertebral disc tissue correlated with water content and proteoglycan content. Spine (Phila Pa 1976). 2009;34(5):520-524.

121. Welsch GH, Trattnig S, Paternostro-Sluga T, et al. Parametric T2 and T2* mapping techniques to visualize intervertebral disc degeneration in patients with low back pain: initial results on the clinical use of 3.0 Tesla MRI. Skelet Radiol. 2011;40(5):543-551.

122. Pfirrmann CW, Metzdorf A, Zanetti M, Hodler J, Boos N. Magnetic resonance classification of lumbar intervertebral disc degeneration. Spine (Phila Pa 1976). 2001;26(17):18731878 .

123. White AA III, Panjabi MM. Clinical Biomechanics of the Spine. Philadelphia, Pennsylvania: Lippincott Williams \& Wilkins; 1990.

124. Urban JP, Roberts S. Degeneration of the intervertebral disc. Arthritis Res Ther. 2003;5(3):120-130.

125. Iatridis JC, MacLean JJ, O'Brien M, Stokes IA. Measurements of proteoglycan and water content distribution in human lumbar intervertebral discs. Spine (Phila Pa 1976). 2007;32(14):1493-1497.

126. Keyes DC CE. The normal and pathological physiology of the nucleus pulposus of the intevertebral disc. JBJS. 1932;14(4):897-938.

127. McNally DS, Adams MA. Internal intervertebral disc mechanics as revealed by stress profilometry. Spine (Phila Pa 1976). 1992;17(1):66-73.

128. Nachemson A. The influence of spinal movements on the lumbar intradiscal pressure and on the tensil stresses in the annulus fibrosus. Acta Orthop Scandinavica. 1963;33(1-4):183207.

129. Adam C, Rouch P, Skalli W. Inter-lamellar shear resistance confers compressive stiffness in the intervertebral disc: an image-based modelling study on the bovine caudal disc. J Biomech. 2015;48(16):4303-4308.

130. Melrose J, Smith SM, Appleyard RC, Little CB. Aggrecan, versican and type VI collagen are components of annular translamellar crossbridges in the intervertebral disc. Eur Spine J. 2008;17(2):314-324.

131. Yu J, Tirlapur U, Fairbank J, et al. Microfibrils, elastin fibres and collagen fibres in the human intervertebral disc and bovine tail disc. J Anat. 2007;210(4):460-471.

132. Pezowicz CA, Robertson PA, Broom ND. The structural basis of interlamellar cohesion in the intervertebral disc wall. J Anat. 2006;208(3):317-330.

133. Brown T, Hansen RJ, Yorra AJ. Some mechanical tests on the lumbosacral spine with particular reference to the intervertebral discs; a preliminary report. J Bone Jt Surg. 1957;39-a(5):1135-1164.

134. Holzapfel GA, Schulze-Bauer CA, Feigl G, Regitnig P. Single lamellar mechanics of the human lumbar anulus fibrosus. Biomech Model Mechanobiol. 2005;3(3):125-140.

135. Kos N, Gradisnik L, Velnar T. A brief review of the degenerative intervertebral disc disease. Med Arch. 2019;73(6):421-424.

136. Hsieh AH, Twomey JD. Cellular mechanobiology of the intervertebral disc: new directions and approaches. $J$ Biomech. 2010;43(1):137-145.

137. Setton LA, Chen J. Mechanobiology of the intervertebral disc and relevance to disc degeneration. J Bone Jt Surg. 2006;88(suppl 2):52-57.

138. Roughley PJ. Biology of intervertebral disc aging and degeneration: involvement of the extracellular matrix. Spine (Phila Pa 1976). 2004;29(23):2691-2699.

139. Vergroesen PP, Kingma I, Emanuel KS, et al. Mechanics and biology in intervertebral disc degeneration: a vicious circle. Osteoarthr Cartil. 2015;23(7):1057-1070.

140. Lyons G, Eisenstein SM, Sweet MB. Biochemical changes in intervertebral disc degeneration. Biochim Biophys Acta. 1981;673(4):443-453.

141. Buckwalter JA. Aging and degeneration of the human 
intervertebral disc. Spine (Phila Pa 1976). 1995;20(11):13071314.

142. Antoniou J, Steffen T, Nelson F, et al. The human lumbar intervertebral disc: evidence for changes in the biosynthesis and denaturation of the extracellular matrix with growth, maturation, ageing, and degeneration. J Clin Investig. 1996;98(4):996-1003.

143. Inoue $\mathrm{N}$, Espinoza Orías AA. Biomechanics of intervertebral disk degeneration. Orthop Clin North Am. 2011;42(4):487-499, vii.

144. Iatridis JC, Setton LA, Weidenbaum M, Mow VC. Alterations in the mechanical behavior of the human lumbar nucleus pulposus with degeneration and aging. J Orthop Res. 1997;15(2):318-322.

145. Brinckmann P, Grootenboer H. Change of disc height, radial disc bulge, and intradiscal pressure from discectomy. An in vitro investigation on human lumbar discs. Spine (Phila Pa 1976). 1991;16(6):641-646.

146. Masuoka K, Michalek AJ, MacLean JJ, Stokes IA, Iatridis JC. Different effects of static versus cyclic compressive loading on rat intervertebral disc height and water loss in vitro. Spine (Phila Pa 1976). 2007;32(18):1974-1979.

147. Huang M, Guo Y, Ye Q, et al. Correlation between T2* (T2 star) relaxation time and cervical intervertebral disc degeneration: An observational study. Medicine. 2016;95(47):e4502. doi:10.1097/MD.0000000000004502

148. Paul CP, Schoorl T, Zuiderbaan HA, et al. Dynamic and static overloading induce early degenerative processes in caprine lumbar intervertebral discs. Plos One. 2013;8(4):e62411. doi:10.1371/journal.pone.0062411

149. Wuertz K, Godburn K, MacLean JJ, et al. In vivo remodeling of intervertebral discs in response to short- and long-term dynamic compression. J Orthop Res. 2009;27(9):1235-1242.

150. Wang DL, Jiang SD, Dai LY. Biologic response of the intervertebral disc to static and dynamic compression in vitro. Spine (Phila Pa 1976). 2007;32(23):2521-2528.

151. Iatridis JC, ap Gwynn I. Mechanisms for mechanical damage in the intervertebral disc annulus fibrosus. $J$ Biomech. 2004;37(8):1165-1175

152. Stefanakis M, Luo J, Pollintine P, Dolan P, Adams MA. ISSLS Prize winner: mechanical influences in progressive intervertebral disc degeneration. Spine (Phila Pa 1976). 2014;39(17):1365-1372.

153. Goel VK, Monroe BT, Gilbertson LG, Brinckmann P. Interlaminar shear stresses and laminae separation in a disc. Finite element analysis of the L3-L4 motion segment subjected to axial compressive loads. Spine (Phila Pa 1976). 1995;20(6):689-698.

154. Iatridis JC, MaClean JJ, Ryan DA. Mechanical damage to the intervertebral disc annulus fibrosus subjected to tensile loading. J Biomech. 2005;38(3):557-565.

155. Fujiwara A, Tamai K, An HS, et al. The relationship between disc degeneration, facet joint osteoarthritis, and stability of the degenerative lumbar spine. J Spinal Disord. 2000;13(5):444-450.

156. Fujiwara A, Lim TH, An HS, et al. The effect of disc degeneration and facet joint osteoarthritis on the segmental flexibility of the lumbar spine. Spine (Phila Pa 1976). 2000;25(23):3036-3044.

157. Li J, Muehleman C, Abe Y, Masuda K. Prevalence of facet joint degeneration in association with intervertebral joint degeneration in a sample of organ donors. J Orthop Res. 2011;29(8):1267-1274.

158. Eubanks JD, Lee MJ, Cassinelli E, Ahn NU. Prevalence of lumbar facet arthrosis and its relationship to age, sex, and race: an anatomic study of cadaveric specimens. Spine (Phila Pa 1976). 2007;32(19):2058-2062.

159. Eubanks JD, Lee MJ, Cassinelli E, Ahn NU. Does lumbar facet arthrosis precede disc degeneration? A postmortem study. Clin Orthop Relat Res. 2007;464184-189. doi:10. 1097/BLO.0b013e3181583d4e

160. Butler D, Trafimow JH, Andersson GB, McNeill TW, Huckman MS. Discs degenerate before facets. Spine (Phila Pa 1976). 1990;15(2):111-113.

161. Fujiwara A, Tamai K, Yamato M, et al. The relationship between facet joint osteoarthritis and disc degeneration of the lumbar spine: an MRI study. Eur Spine $J$ 1999;8(5):396-401.

162. An HS, Masuda K, Inoue N. Intervertebral disc degeneration: biological and biomechanical factors. $J$ Orthop Sci. 2006;11(5):541-552.

163. Bashkuev M, Reitmaier S, Schmidt H. Relationship between intervertebral disc and facet joint degeneration: a probabilistic finite element model study. J Biomech. 2020;102:109518. doi:10.1016/j.jbiomech.2019.109518

164. Park WM, Kim K, Kim YH. Effects of degenerated intervertebral discs on intersegmental rotations, intradiscal pressures, and facet joint forces of the whole lumbar spine. Comput Biol Med. 2013;43(9):1234-1240.

165. Kirkaldy-Willis WH, Wedge JH, Yong-Hing K, Reilly J. Pathology and pathogenesis of lumbar spondylosis and stenosis. Spine (Phila Pa 1976). 1978;3(4):319-328.

166. Cao L, Guilak F, Setton LA. Three-dimensional finite element modeling of pericellular matrix and cell mechanics in the nucleus pulposus of the intervertebral disk based on in situ morphology. Biomech Model Mechanobiol. 2011;10(1):1-10.

167. Iatridis JC, Weidenbaum M, Setton LA, Mow VC. Is the nucleus pulposus a solid or a fluid? Mechanical behaviors of the nucleus pulposus of the human intervertebral disc. Spine (Phila Pa 1976). 1996;21(10):1174-1184.

168. Johannessen W, Elliott DM. Effects of degeneration on the biphasic material properties of human nucleus pulposus in confined compression. Spine (Phila Pa 1976). 2005;30(24):E724-729.

169. Elliott DM, Setton LA. Anisotropic and inhomogeneous tensile behavior of the human anulus fibrosus: experimental measurement and material model predictions. $J$ Biomech Eng. 2001;123(3):256-263.

170. Guerin HL, Elliott DM. Quantifying the contributions of structure to annulus fibrosus mechanical function using a nonlinear, anisotropic, hyperelastic model. J Orthop Res. 2007;25(4):508-516.

171. Guerin HA, Elliott DM. Degeneration affects the fiber reorientation of human annulus fibrosus under tensile load. $J$ Biomech. 2006;39(8):1410-1418.

172. Ellingson AM, Nagel TM, Polly DW, Ellermann J, Nuckley DJ. Quantitative T2* (T2 star) relaxation times predict site specific proteoglycan content and residual mechanics of the intervertebral disc throughout degeneration. J Orthop Res. 2014;32(8):1083-1089.

173. Nguyen AM, Johannessen W, Yoder JH, et al. Noninvasive quantification of human nucleus pulposus pressure 
with use of T1rho-weighted magnetic resonance imaging. $J$ Bone Jt Surg. 2008;90(4):796-802.

174. Ellingson AM, Mehta H, Polly DW, Ellermann J, Nuckley DJ. Disc degeneration assessed by quantitative T2* (T2 star) correlated with functional lumbar mechanics. Spine (Phila Pa 1976). 2013;38(24):E1533-1540.

175. Karchner JP, Yousefi F, Bitman SR, Darvish K, Pleshko N. Non-destructive spectroscopic assessment of high and low weight bearing articular cartilage correlates with mechanical properties. Cartilage. 2019;10(4):480-490.

176. Bible JE, Simpson AK, Emerson JW, Biswas D, Grauer JN. Quantifying the effects of degeneration and other patient factors on lumbar segmental range of motion using multivariate analysis. Spine (Phila Pa 1976). 2008;33(16):1793-1799.

177. Lee SH, Daffner SD, Wang JC, Davis BC, Alanay A, Kim JS. The change of whole lumbar segmental motion according to the mobility of degenerated disc in the lower lumbar spine: a kinetic MRI study. Eur Spine J. 2015;24(9):1893-1900.

178. McGlashen KM, Miller JA, Schultz AB, Andersson GB. Load displacement behavior of the human lumbo-sacral joint. J Orthop Res. 1987;5(4):488-496.

179. O'Connell GD, Jacobs NT, Sen S, Vresilovic EJ, Elliott DM. Axial creep loading and unloaded recovery of the human intervertebral disc and the effect of degeneration. J Mech Behav Biomed Mater. 2011;4(7):933-942.

180. Bisschop A, van Dieën JH, Kingma I, et al. Torsion biomechanics of the spine following lumbar laminectomy: a human cadaver study. Eur Spine J. 2013;22(8):1785-1793.

181. O'Connell GD, Malhotra NR, Vresilovic EJ, Elliott DM. The effect of nucleotomy and the dependence of degeneration of human intervertebral disc strain in axial compression. Spine (Phila Pa 1976). 2011;36(21):1765-1771.

182. Showalter BL, Malhotra NR, Vresilovic EJ, Elliott DM. Nucleotomy reduces the effects of cyclic compressive loading with unloaded recovery on human intervertebral discs. J Biomech. 2014;47(11):2633-2640.
183. Adams MA, McNally DS, Dolan P. 'Stress' distributions inside intervertebral discs. The effects of age and degeneration. J Bone Jt Surg. 1996;78(6):965-972.

184. Skrzypiec DM, Pollintine P, Przybyla A, Dolan P, Adams MA. The internal mechanical properties of cervical intervertebral discs as revealed by stress profilometry. Eur Spine J. 2007;16(10):1701-1709.

185. Bezci SE, Nandy A, O’Connell GD. Effect of hydration on healthy intervertebral disk mechanical stiffness. $J$ Biomech Eng. 2015;137(10):101007. doi:10.1115/1.4031416

186. Farhang N, Stover J, Lawrence B, Bowles RD. Chapter 2: Pathophysilogy of disc disease: disc degeneration. In: Härtl R, Bonassar LJ, eds. Biological Approaches to Spinal Disc Repair and Regeneration for Clinicians. New York: Thieme Medical Publishers; 2017:11-19.

Disclosures and COl: Roger Härtl is a consultant for Ulrich, Brainlab, DePuy-Synthes, and he has royalties from Zimmer. The authors received no funding for this study.

Corresponding Author: Roger Härtl, MD, Department of Neurological Surgery, Weill Cornell Brain and Spine Center, New York-Presbyterian Hospital, 525 East 68th Street, Box 99, New York, NY 10065. Phone: (212) 746-2152; Fax: (212) 7468947; Email: roh9005@med.cornell.edu.

Published 30 April 2021

This manuscript is generously published free of charge by ISASS, the International Society for the Advancement of Spine Surgery. Copyright (C) 2021 ISASS. To see more or order reprints or permissions, see http://ijssurgery.com. 